\title{
PENGARUH PENGGUNAAN TEPUNG DAUN MENGKUDU (Morinda cirifolia) DALAM PAKAN TERHADAP KUALITAS FISIK TELUR AYAM \\ (Effect of Noni Leaf Meal in The Diet On Chicken Eggs Fisis Quality)
}

\author{
Trianto, Y. 1), Hintono, A ${ }^{2)}$ dan Mahfudz, L. $D^{3)}$ \\ ${ }^{1)}$ Mahasiswa Program S1 Fakultas Peternakan dan Pertanian Universitas Diponegoro \\ Jl. Prof. H. Soedarto, SH, Tembalang, Semarang 50275 \\ Email : inditik@yahoo.com \\ ${ }^{2,3)}$ Staf Pengajar Fakultas Peternakan dan Pertanian Universitas Diponegoro \\ Jl. Prof. H. Soedarto, SH, Tembalang, Semarang 50275
}

Diterima : 25 Januari 2017 Disetujui : 18 Mei 2017

\begin{abstract}
ABSTRAK
Penelitian ini bertujuan untuk mengkaji pengaruh penggunaan tepung daun mengkudu (Morinda cirifolia) dalam pakan terhadap kualitas fisik telur ayam. Materi yang digunakan sebanyak 200 ekor ayam petelur umur 22 minggu dengan bobot badan $1513,5 \pm 13,67$ g. Bahan pakan yang digunakan adalah konsentrat, jagung kuning, bekatul, dan tepung daunmengkudu. Rancangan yang digunakan adalah Acak Lengkap terdiri dari 4 perlakuan dengan 5 kali ulangan dan tiap unit percobaan terdiri dari 10 ekor ayam petelur. Pakan perlakuan yang digunakan antara lain T0 (kontrol) = ransum tanpa penggunaan tepung daun mengkudu; $\mathrm{T} 1$ = ransum dengan penggunaan tepung daun mengkudu, $\mathrm{T} 1=$ ransum dengan penggunaan tepung daun mengkudu 2,5\%; $\mathrm{T} 2=$ ransum dengan penggunaan tepung daun mengkudu 5\%; dan $\mathrm{T} 3=$ ransum dengan penggunaan tepung daun mengkudu 7,5\%;. Variabel yang diamati adalahtebal cangkang, haugh unit dan skor warna kuning telur. Data dianalisis menggunakan analisis ragam (ANOVA) dari Rancangan Acak Lengkap (RAL) dan apabila terdapat perbedaan dilanjutkan dengan Uji Jarak Berganda Duncan's. Hasil penelitian menunjukkan bahwa penggunaan tepung daun mengkudu (Morinda cirifolia) dalam pakan tidakberpengaruhnyata $(\mathrm{P}>0,05)$ terhadap haugh unitnamunberpengaruh nyata $(\mathrm{P}<0,05)$ terhadap tebalcangkangdan skor warnakuningtelur. Simpulan dari penelitian ini adalah penggunaan tepung daun mengkudu tidak menurunkan nilai haugh unit, namun dapat meningkatkan tebal cangkang dan warna kuning telur ayam.
\end{abstract}

Kata Kunci : AyamPetelur, Tepung daun mengkudu danKualitas FisikTelur

\begin{abstract}
The research aimed to study the effect of noni leaf meal in the diet on chicken eggs fisis quality. The material used was 200laying hens, aged 22 weeks with initial body weight $(B W)$ average of 1513,5 $\pm 13,67$ gram $(C V=2,02 \%)$. Feedstuffs used were concentrate, yellow corn, rice bran, and noni leaf meal.The experimentused Completely Randomized Design with 4 treatments of ration, each consisted of 5 replications of 10 layer hens. The treatments given were TO (control) $=$ feed without noni leaf meal; $T 1=$ feed with $2,5 \%$ noni leaf meal; $T 2=$ feed with 5\% noni leaf meal; and T3 : feed with 7,5\% noni leaf meal. Variables measured wereeggshell thickness, haugh unit and yolk color score.Data were
\end{abstract}


subjected to analysis of variance (ANOVA) of the Completely Randomized Design (CRD), if significant results were obtanined, then followed by Duncan's Multiple Range Test. The result of the research showed thatthe use of noni leaf meal in the diet did not significantly affected $(P>0,05)$ haugh unit, but it significantly affected $(P<0,05)$ eggshell thickness and yolk color score. Based on this research result, it was concluded that use of noni leaf meal in the diet did not increase haugh unit, but decrased eggshell thickness and yolk color score.

Keyword : Laying Hens, Noni Leaf Meal, Egg Fisis Quality.

\section{PENDAHULUAN}

Peranan telur dalam kehidupan sehari-hari di masyarakat Indonesia tampak semakin penting. Hal ini disebabkan karena harga telur relatif murah sehingga dapat dijangkau oleh masyarakat, mudah didapat, mudah disajikan, dan bioaktifnya tinggi.Disamping mengandung kadar protein yang tinggi, telur juga merupakan sumber zat besi, beberapa mineral lain dan vitamin, sehingga telur merupakan bahan pangan hewani yang dapat dikonsumsi oleh manusia pada segala umur.

Telur mempunyai kekurangan secara fisik dan kimiawi. Keadaan fisik mencakup hal berat telur, kondisi cangkang telur (tipis dan tebal) dan kebersihan cangkang telur. Standar ukuran dalam pemasaran telur adalah 56,7 gram per butir (Sumarni dan Nan Djuarnani, 1995). Kulit yang tipis relatif berpori lebih banyak dan besar, sehingga mempercepat turunnya kualitas telur akibat penguapan dan pembusukan lebih cepat. Semakin kotor keadaan cangkang telur maka semakin banyak mikroba masuk melalui pori-pori dan mengakibatkan kerusakan telur yang lebih cepat. Kerusakan bagian luar telur mempengaruhi kualitas fisik bagian dalam yang dapat mengakibatkan kuning dan putih telur tercampur. Selain itu, salah satu faktor kekurangan yang mempengaruhi penerimaan masyarakat terhadap kualitas fisik telur adalah warna kuning telur.
Konsumen pada umumnya lebih memilih telur ayam yang kuning telurnya berwarna kemerahan sehingga memiliki skor warna kuning antara 11-13.Total lemak dalam kuning telur adalah sebesar 29,98\% dari bobot kuning telur dan kolesterol sebesar 5,20\% dari bobot kuning telur (Rahayu, 2003).

Komposisi fisik dan kualitas telur dipengaruhi oleh beberapa faktor, diantaranya bangsa ayam, umur, musim, penyakit dan lingkungan, pakan yang diberikan serta sistem pemeliharaan. Pakan merupakan salah satu faktor yang paling penting dalam menentukan kualitas fisik telur.Pakan yang berkualitas baik akan menghasilkan telur yang berkualitas baik pula. Namun perlu diberikan pakan alternatif untuk menekan biaya produksi. Pakan alternatif sebaiknya memiliki kandungan nutrisi yang tinggi, mudah didapat dan diolah serta tidak menimbulkan bahaya bagi ternak yang memakannya. Salah satu pakan alternatif yang dapat digunakan adalah tanaman mengkudu.

Daun mengkudu mengandung zat nutrisi seperti protein kasar $22,11 \%$, Ca 10,30\%, Fe 437 ppm, Zn 35,80 ppm dan $\beta$ karoten 161 ppm (Wardiny dan Sinar, 2008). Daun mengkudu memilki kandungan Ca yang tinggi berperan dalam kualitas cangkang atau kerabang telur. Pada daun mengkudu juga memiliki $\beta$-karoten yang berfungsi sebagai pigmen warna pada 
kuning telur yang diharapkan dapat meningkatkan skor warna kuning telur.

Berdasarkan uraian diatas maka perlu dilakukan penelitian yang menggunakan tepung daun mengkudu sebagai salah satu bahan ransum unggas karena selain yang mengandung gizi cukup tinggi, harganya murah dan ketersediaannya melimpah.

Tujuan dari penelitian ini adalah untuk mengetahui pengaruh penggunaan tepung daun mengkudu (Morinda cirifolia) dalam pakan terhadap kualitas fisik telur.Adapun sifat fisik yang diukur adalah tebal cangkang, haugh unit dan skor warna kuning telur.

\section{MATERI DAN METODE}

\section{Materi}

Penelitian tentang pengaruh penggunaan tepung daun mengkudu (Morinda cirifolia) dalam pakan terhadap warna kuning dan indeks haugh telur dilaksanakan selama 2 bulan dimulai pada tanggal 20 Oktober 2014 sampai dengan 20 Desember 2014 di Desa Mijen, Kecamatan Mijen Kota Semarang.

Materi yang digunakan dalam penelitian ini ayam petelur periode layer strain Isa Brown berumur 22 minggu sebanyak 200 ekordengan bobot badan $1513,5 \pm 13,67 \mathrm{~g}$ ditempatkan di kandang baterai berupa kotak yang terbuat dari kawat. Bahan pakan yang digunakan dalam penelitian ini adalah konsentrat, jagung kuning, bekatul, dan tepung daun mengkudu.

\section{Metode}

Penelitian ini menggunakan rancangan acak lengkap (RAL) terdiri dari 4 perlakuan. Masing-masing perlakuan terdiri dari 5 ulangan,setiap unit percobaan terdiri dari 10 ekor ayam petelur umur 22
minggu.Pengolahan data dilakukan dengan prosedur analisis Ragam (analysis of variance / anova) dan dilanjutkan dengan Uji Wilayah Berganda Duncan pada taraf $5 \%$.

Perlakuan penggunaan tepung daun mengkudu, yaitu

T0 : perlakuan tanpa penggunaan tepung daun mengkudu

$\mathrm{T} 1$ : pakan dengan penggunaan $2,5 \%$ tepung daun mengkudu.

T2 : pakan dengan penggunaan $5 \%$ tepung daun mengkudu.

T3 : pakan dengan penggunaan $7,5 \%$ tepung daun mengkudu.

Komposisi dan kandungan gizi masing - masing ransum penelitian tertera Tabel 1.Ransum yang diberikan dengan protein 16-17\% dan diberikan sebanyak 120 gram/ekor/hari. 
Tabel 1. Komposisi dan Kandungan Nutrisi Ransum

\begin{tabular}{lrrrr}
\hline \multirow{2}{*}{ BahanPakan } & \multicolumn{1}{c}{ T0 } & \multicolumn{1}{c}{ T1 } & \multicolumn{1}{c}{ T3 } \\
\cline { 2 - 5 } & \multicolumn{4}{c}{$--------\%------$} \\
\\
\hline Tepungdaunmengkudu & 0,00 & 2,50 & 5,00 & 7,50 \\
Konsentrat & 35,00 & 34,00 & 34,00 & 34,00 \\
Jagunggilingkuning & 50,00 & 50,00 & 50,00 & 50,00 \\
Dedakhalus & 15,00 & 13,50 & 11,00 & 8,50 \\
\hline Total & 100,00 & 100,00 & 100,00 & 100,00 \\
\hline KandunganNutrisi: & & & \\
EM (Kkal/kg) & $3.480,35$ & $3.468,97$ & $3.465,69$ & $3.462,42$ \\
Protein Kasar (\%) & 16,75 & 16,69 & 16,88 & 17,06 \\
SeratKasar (\%) & 4,74 & 5,25 & 5,695 & 6,14 \\
LemakKasar (\%) & 5,14 & 5,16 & 5,18 & 5,19 \\
Calsium (\%) & 4,23 & 4,17 & 4,22 & 4,28 \\
Phospor (\%) & 0,88 & 0,85 & 0,82 & 0,79 \\
\hline
\end{tabular}

Keterangan : Kandungan gizi berdasarkan perhitungan hasil analisis proksimat bahan pakan di Laboratorium Pusat Studi Pangan dan Gizi Universitas Gadjah Mada, 2014.

Parameter penelitian dan cara $\mathrm{h}$ : tinggi putih telur kental (mm) pengambilan data dalam penelitian ini meliputi ketebalan cangkang, haugh unit, dan warna kuning telur. Pengambilan data dimulai pada minggu ketiga sebelum penelitian berakhir. Pengambilan data diawali dengan mempersiapkan peralatan berupa timbangan digital, dept micrometer, kaca datar,micrometer, dan yolk color fan.

Pengukuran tebal kerabang dilakukan dengan menggunakan mikrometeryang terdiri dari 3 bagian telur yaitu bagian ujung atau lancip, bagian tengah dan bagian bawah atau tumpul dengan menggunakan micrometer dinyatakan $\mathrm{mm}$, Pengukuran Haugh Unit untuk mengetahui kekentalan telur, ditentukan berdasarkan hubungan logaritma tinggi albumen (mm) dengan berat telur (g) dilakukan dengan menimbang berat telur dan mengukur tinggi albumen menggunakan tripold mikrometer, selanjutnya dihitung menggunakan rumus Austic dan Nesheim (1990):

$\mathrm{HU}=100 \log \left(\mathrm{h}+7,57-1,7 \mathrm{~W}^{0,73}\right)$

Keterangan :

$\mathrm{H}$ : Haugh Unit

$\mathrm{W}$ : berat telur utuh $(\mathrm{g})$

Warna kuning telur diukur dengan yolk color fan dengan angka pengukur 1 15. Semakin besar angka pengukur maka semakin gelap warna telur yang diperoleh.

\section{HASIL DAN PEMBAHASAN}

\section{Pengaruh Perlakuan terhadap Tebal Cangkang}

Rataan tebal cangkang pada telur ayam yang diperoleh adalah T0 sebesar 0,4075 mm,T1 sebesar $0,4220 \mathrm{~mm}$, T2 sebesar $0,4380 \mathrm{~mm}$, dan T3 sebesar 0,4600 $\mathrm{mm}$. Hasil analisis secara statistik menunjukkan bahwa perlakuan ransum dengan penggunaan tepung daun mengkudu menunjukkan berpengaruh nyata $(p<0,05)$ terhadap tebal cangkang. Hal ini disebabkan kandungan $\mathrm{Ca}$ dan $\mathrm{P}$ pada daun mengkudu yang tinggi. Proses pembentukan cangkang sangat dipengaruhi kandungan zat gizi dalam pakannya. Diperlukan ketersediaan cukup mineral pembentuk deposit atau partikel kapur, yaitu garam-garan kalsium $(\mathrm{Ca}, \mathrm{P})$ dalam jumlah dan mutu yang cukup. 
Ketebalan cangkang telur banyak

2004).Selanjutnya Achmanu

(2010)

dipengaruhi oleh kadar kalsium dalam menyatakan bahwa semakin tebal cangkang ransum yang akan menentukan ketersediaan telur berarti kandungan $\mathrm{Ca}$ juga semakin garam-garam kalsium dalam darah untuk tinggi.

pembentukan telur (Yuwanta,

Tabel 2. Rata-rata Tebal Cangkang, Skor Warna Kuning Telur dan Haugh Unit Ayam Petelur.

\begin{tabular}{clcc}
\hline Perlakuan & \multirow{2}{*}{ Tebal Cangkang $(\mathrm{mm})$} & $\begin{array}{c}\text { Skor Warna Kuning } \\
\text { Telur }\end{array}$ & Haugh Unit \\
\hline T0 & $0,41^{\mathrm{c}}$ & $8,00^{\mathrm{c}}$ & $90,38^{\mathrm{ns}}$ \\
T1 & $0,42^{\mathrm{ab}}$ & $10,20^{\mathrm{ab}}$ & $92,77^{\mathrm{ns}}$ \\
T2 & $0,44^{\mathrm{bc}}$ & $10,00^{\mathrm{b}}$ & $87,46^{\mathrm{ns}}$ \\
T3 & $0,46^{\mathrm{a}}$ & $11,00^{\mathrm{a}}$ & $85,35^{\mathrm{ns}}$ \\
\hline
\end{tabular}

Keterangan : 1) nilai rata-rata dengan huruf berbeda pada kolom yang sama menunjukkan perbedaan nyata $(\mathrm{P}<0,05)$.

2) ns : tidak berbeda nyata $(\mathrm{P}>0,05)$.

\section{Pengaruh Perlakuan terhadap Haugh} Unit

Rataan indeks haugh pada telur ayam yang diperoleh adalah T0 sebesar 90,38,T1 sebesar 92,77, T2 sebesar 87,46 dan T3 sebesar 85,35. Hasil analisis secara statistik menunjukkan bahwa perlakuan ransum dengan penggunaan tepung daun mengkudu menunjukkan tidak berpengaruh nyata $(p<0,05)$ terhadap indeks haugh. Hal ini disebabkan pengamatan dilakukan dengan waktu yang sama saat pengambilan telur dan dalam kondisi segar.Stadelman and Cotterill (1977)menyatakan bahwa nilai HU tergantung pada tinggi rendahnya bobot telur dan tebal albumen. Jika bobot telur menurun akibat penyimpanan, maka ada kecenderungan tebal albumen dan nilai $\mathrm{HU}$ akan menurun juga

\section{Pengaruh Perlakuan terhadap Warna Kuning Telur}

Rataan warna kuning telur ayam yang diperoleh adalah T0 sebesar 8, T1 sebesar 10, T2 sebesar 10, dan T3 sebesar 11. Hasil analisis secara statistik menunjukkan bahwa perlakuan ransum dengan penggunaan tepung daun mengkudu menunjukkan pengaruh nyata $(\mathrm{p}<0,05)$ terhadap warna kuning telur. Hal ini disebabkan warna atau pigmen yang terdapat dalam kuning telur sangat dipengaruhi oleh beta-karoten dari tepung daun mengkudu.

Pakan mempengaruhi warna dari kuning telur, yaitu bahan pakan yang mengandung pigmen karotenoid terutama pigmen beta karoten dan xantofil. Bahan pakan yang banyak mengandung pigmen betakaroten dan xantofildiantaranya banyak terkandung pada hijauan atau daun-daunan (Sujana et al 2006). Pewarnaan kuning telur yang optimal pada umumnya disebabkan kayanya kandungan karoten dalam ransum (Hamilton et al., 1990; Lai et al.,1996).Unggas mengkonsumsi ransum yang mengandung karotenoid lebih tinggi akan menghasilkan telur dengan intensitas warna kuning telur yang lebih tinggi pula (Udedibie \& Opara, 1998). 


\section{KESIMPULAN DAN SARAN}

\section{Kesimpulan}

Kesimpulan dari penelitian ini adalah penggunaan tepung daun mengkudu tidak menurunkan nilai haugh unit, namun dapat meningkatkan tebal cangkang dan warna kuning telur ayam.

\section{DAFTAR PUSTAKA}

Achmanu, Muharlien dan R. Fajar.2010. Efek Lantai Kandang (Renggang dan Rapat) Dan Imbangan Jantan Betina Terhadap Fertilitas, Daya Tetas dan Kematian Embrio pada Burung Puyuh (Coturnix-Coturnix japonica). JIIPB 20(1) : 48-54

Austic, R. E. and M. C. Nesheim. 1990. Poultry Production. 13th Ed. Lea and Febiger, Washington.

Hamilton, D.B., F.J. Tirado and F. GarciaHernandez.1990. Deposition in egg yolks of the carotenoids fromsaponified and unsaponified oleoresin of red peper(Capsicum annuum) fed to laying hens. Poult. Sci. 69:462-470.

Lai,S.M.,J.I.Gray,C.J.Flegaland T. Cooper. 1996. Deposition of carotenoids in eggs from hens fed diets containing saponified and unsaponified oleoresin paprika. J. Sci. Food Agric. 72: 166-170

Rahayu, W.P. dkk. 2003. Klarifikasi Bahan Pangan dan Resiko Keamanannya. PT Gramedia Pustaka Utama, Jakarta.

Stadelman, W.J. and O.J. Cotterill, 1977. Egg Science and Technology, 2nd Ed. Avi Publishing Company Inc.West Port Connecticut.
Sujana, E., Wahyuni, S. dan Burhanudin, H. 2006. Efek Pemberian Ransum yang Mengandung Tepung Daun Singkong, Daun Ubi Jalar, dan Eceng Gondok sebagai Sumber Pigmen Karotenoid Terhadap Kualitas Kuning Telur Itik Tegal. Jurnal Ilmu Ternak. Juni 2006. Vol. 6. No. 1,53-56

Sumarni dan Nan Djuarnani . 1995. Diktat

Penanganan Pasca Panen Unggas.

Departemen Pertanian. Balai

Latihan Pertanian, ternak, Ciawi Bogor.

Udedibie, A.B.I. \& C.C. Opara.1998.

Responses of growing broilers and laying hens to the dietary inclusion of leaf meal from Alchorniacordifolia. Animal Feed Sci. and Tech. 71:157-164

Wardiny, T.M. dan Sinar, T.E.A. 2008. Pengaruh Pemberian Mengkudu (Morinda cirifolia) terhadap Kandungan Kolesterol Telur Ayam. Laporan Penelitian.

UniversitasTerbuka-Jakarta.

Yuwanta, T. 2010. Pemanfaatan Kerabang Telur. Program Studi Ilmu dan Industri Peternakan. Fakultas Peternakan. Universitas Gajah Mada. Yogyakarta. 